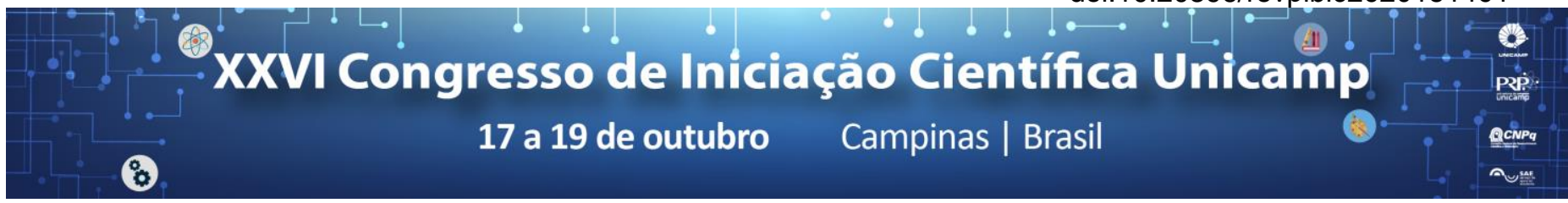

\title{
USO DE FERRAMENTAS DE PROGRAMAÇÃO PARA PRODUÇÃO DE RECURSOS DIDÁTICOS PARA MATEMÁTICA E CIÊNCIAS.
}

\section{Vinicius Gomes*, Thayná Soares, Lucas H. Barbosa, Ricardo de Oliveira Anido}

\section{Resumo}

O objetivo proposto neste trabalho foi aprender a criar jogos didáticos mais facilmente, utilizando a linguagem de programação Scratch. O propósito desses jogos didáticos é estimular os alunos do ensino fundamental I e II a aprender por esses meios simples e divertidos.

\section{Palavras-chave: \\ Programação, Produção, Didático.}

\section{Introdução}

O objetivo principal do projeto é utilizar jogos e simulações criados em Scratch como ferramenta de aprendizado de ciências e matemática para alunos do ensino fundamental. Um objetivo secundário é mostrar a professores que com o básico da programação é possível ao menos adaptar para seus fins didáticos, os jogos e simulações apresentados.

\section{Resultados e Discussão}

Aprendemos a usar muitas funções do Scratch, colocamos projetos em prática, fizemos exercícios na linguagem Python também, porém, não chegamos a projetar nada nesta linguagem.

\section{Conclusões}

Um elemento significativo a se apresentar é o processo de relação que nós temos que criar para progredir no estudo e alcançar o objetivo final. Nessa questão nosso grupo criou uma boa relação em um curto período de tempo, facilitando nosso desenvolvimento no projeto. Outro aspecto relevante que podemos considerar são ferramentas que nos foram oferecidas. Para uso indireto, nos foi apresentado o PhET, um site que é constituído por simulações interativas de ciências e matemática. Esse site nos foi cedido para buscar inspiração para utilizar em nossas próprias criações. Para uso direto nos foi oferecido o Scratch, um site que tem como base uma linguagem da programação simples, de rápido entendimento e de fácil uso. O Scratch é o nosso alicerce para a criação de jogos didáticos e temos o intuito de criar uma biblioteca de jogos até o término do curso. 